\title{
Evaluation the Solidification/Stabilization of Heavy Metals by Portland Cement
}

\author{
Ghayda Yaseen Al-Kindi ${ }^{1}$ \\ 1 Sanitary and Environmental Branch, University of Technology, 10009, Baghdad, Iraq \\ e-mail: Al.kindi.ghydaa@gmail.com, 40126@uotechnology.edu.iq
}

\begin{abstract}
Numerous solutions are used in the site to treat pollution, including remediation of heavy metals and hazardous wastes by solidification/stabilization $(\mathrm{S} / \mathrm{S})$ with cement as a binder. $\mathrm{S} / \mathrm{S}$ is one of the most commonly methods used for treating inorganic wastes. The objective of this research was using unconfined compressive strength test, and EPA Toxicity Leaching Procedure TCLP method 1313, to test the effectiveness performance, and efficiency of the solidification / stabilization method for treatment of some heavy metals ( $\mathrm{Fe}, \mathrm{Zn}, \mathrm{Mn}, \mathrm{Cr}$ ) contaminated sands using ordinary locally produced Portland Cement type A. In this study, three loads of pollution in three mix designs by contaminated sands were used. As a result of the unconfined compression test, it was observed that the value 1-15 MPa with OPC cement content $25 \%$ in the solidification / stabilization process was good enough to comply with the limited value set by the (US EPA). In addition, the concentration of zinc ions was $500 \mathrm{~kg} / \mathrm{mg}, 1500 \mathrm{~kg} / \mathrm{mg}$, and $3000 \mathrm{~kg} / \mathrm{mg}$, which caused an increase in compressive strength in the early period of age, and a decrease at a later age. An increase in the iron ion concentration caused an increase in the compressive strength at a later age, the effective retention percentages were $(97,93.5,96$ and 92) for iron, zinc, manganese and chromium ions, respectively, which exceeded $3000 \mathrm{mg} / \mathrm{kg}$ initially. The high effectiveness in holding and retaining metals within the matrix of solidification / stabilization at the particle size above $9.5 \mathrm{~mm}$ was found as well. The samples ( $\mathrm{Mn}$ and $\mathrm{Cr}$ ) with the low amount of cement in the mix treatment were not able to retain the required TCLP regulatory limits value, and the initial extraction $\mathrm{pH}$ 4.9. However, the final $\mathrm{pH} 9.5$ is alkanet and stabilization effects of the cement matrix.
\end{abstract}

Keywords: solidification/stabilization, binder, cement, leaching, hazards waste

\section{INTRODUCTION}

The last step that has become a widely used technology for hazardous industrial waste treatment steps before disposal involves solidification and stabilization $(\mathrm{S} / \mathrm{S})$ processes (Cioffi et al. 2002). Solidification and stabilization is a sophisticated technology for the treatment of contaminated soil, sediment, sludge and waste (i.e. contaminated material), also used for the treatment of radioactive waste in the $1950 \mathrm{~s}$, while in the 1970s it was used to treat hazardous waste (Conner, et al. 1998). This process is aimed at reducing the risk of hazardous substances in the filtration of air, plants, soil, surface and groundwater, making the best use of limited solid waste, and improving waste treatment (Conner, et al., 1998). S/S is the process of blending treatment reagents into contaminated material to impart physical and/or chemical changes, thus reducing the environmental impact of contaminated water on groundwater or on surface water. The main advantages of cement in $\mathrm{S} / \mathrm{S}$ processes with other bonding agents include comparative low cost, non-toxicity of the chemical ingredients, chemical and physical long-term stability, high compressive and impact strength, biodegradation resistance, low water permeability, as well as ease of use and processing (Shi and Spence, 2004).

The S/S technology is considered to be environmentally friendly (Tomasevic et al., 2013) because pollutants can be chemically stabilized and the environmental risk associated with the pollution is dramatically reduced (Rijkenberg and Depree, 2010). In many parts of the world, there are new restrictions on landfill, waste collection from land disposal, as well as increasing land costs and large repair requirements. The $\mathrm{S} / \mathrm{S}$ technique 
is still considered an affordable method because it makes the waste acceptable for land filling disposal (Wiles, 1987). In the S/S method, the waste materials treatment through change in physical and chemical properties of contaminations, or a group of cleaning up methods which slow down the release of harmful chemicals from polluted soil or sludge are determined. During physical and chemical processes, the hazardous substances and environmental pollutants are reduced (Kitamura et al., 2002). Through the S/S technology, soil and sediment contaminants treated by blending the contaminant with bonding agents or additives to reduce the mobility of toxic substances. The purpose is to contain and reduce contaminants and prevent the pollutants release into the environment (Malviya and Chaudhary, 2006).

The bonding materials are used to bind the contaminants together, producing the coupling in the $\mathrm{S} / \mathrm{S}$ method that enables the reuse of the product in a useful manner, increase the importance of the materials of the chemical stability and the physical solidity of the processed product. Most of the binding factors are known as having high $\mathrm{pH}$ levels. High $\mathrm{pH}$ of pollutants during precipitation and the rise of acidity reduce the solubility of pollutants and thus the risk and distribution of the environment, (Kimbrough et al., 1999). These additives lead to the deposition of pollutants and reduce their mobility (stabilization). The other benefit of the bonding material is its ability to compress itself into a solid cone, leading to the packaging of pollutants in a physical process (solidification).

In general, the main choices between the various binding agents used in the treatment of $\mathrm{S} / \mathrm{S}$ which must have the ability to A - chemically bond the free liquid, $\mathrm{B}$ - reduce the permeability of waste, $\mathrm{C}$ - encapsulate waste particles surrounding them with an impermeable coating, D - reduce the solubility of waste to repair of hazardous components chemically, E - facilitate reducing the toxicity of some contaminants.

Stabilization refers to the reduction of chemical hazards by decreasing solubility, mobility or toxicity and not changing the physical nature not necessarily changed by stabilization (Coz et al., 2004). Solidification refers to the packaging of the waste with a solid material. It does not necessarily mean that a chemical reaction between the pollutant and solid additives may be a monolithic block, a clay-like material, a granular particulate, or some other physical form commonly considered "solid" (Cioffi et al., 2002)
In Iraq and many developing countries, it has become necessary to seek the disposal methods that are acceptable from the economic and social standpoints. The U.S. Environmental Protection Agency (EPA) has identified S/S as the bestdemonstrated available technology for 57 RCRA. (Resource Conservation and Recovery Act) listed hazardous wastes. In addition, the S/S technology was selected in $24 \%$ of all source control treatments at Superfund remedial action sites in the United States (U.S. EPA 2004). Several studies on industrial and municipal waste disposal sites showed evidence of the escape of contaminants from these wastes, which adversely affect the well-being of people. If released into the environment, they may also affect the hydrogen cycle and food chain (Hansen, et al., 1984). Three main products are produced by rapid cement reaction with water: Hydrated Calcium Silicates (C2SHx, C3S2 Hx) known by calcium Silicate Hydrate gels (C-S-H), Hydrated Calcium aluminates (C3AHx, C4AHx) and Hydrated Lime $\mathrm{Ca}(\mathrm{OH})$. The action rate of pure cement phases is usually arranged in the increasing order (Chen, 2009).

$$
\mathrm{C} 3 \mathrm{~A}>\mathrm{C} 3 \mathrm{~S} \sim \mathrm{CA}>\mathrm{C} 4 \mathrm{AF}>\mathrm{C} 2 \mathrm{~S}
$$

The cement particles bind with adjacent granules together, because of these interactions and form a hard Skelton Matrix, In addition, the cement hydration process increases the $\mathrm{pH}$ of water present in the soil pores due to the dissociation of the hydrated lime. During the last decade, the literature concerning the application of cementbased $\mathrm{S} / \mathrm{S}$ for industrial sludge has spread into hazardous waste management. The following examples were listed: evaluation of the effectiveness of the stabilization and solidification of heavy metals from an electroplating industry sludge (Silva et al., 2007); the use of granulated fly ashes from power plants with $20 \%$ proportion of phosphogypsum waste from the production of phosphoric acid in the production of cement and their impact on the hardening of cement mortar. It has been shown that the cement with $20 \%$ of shredded granules meets the requirements of strength for class 32.5. The cement mortar was made and the properties were compared with typical mortar prepared from ash with gypsum. It was found that the tested cement mortar have a longer setting time. However, both types of mortar had similar compressive strengths and flexural strengths after hardening for twenty-eight days 
(Borowski and Hycnar, 2016). The mortar mixes were made by replacing the masonry cement with up to $50 \%$ of fly ash at an incremental rate of $10 \%$. Six mortar mixes with 1:4 volumetric cement-to-aggregate ratios using natural sand were made and tested for flow and strength properties. It was found that the addition of fly ash increased the flow, when the replacement levels were above $40 \%$. Mortar with high volume fly ash has to attain a comparable strength with that of the control mix. The results have demonstrated that high volume replacement of fly ash is a viable alternative for producing environmentally friendly masonry mortar (Balamohan, 2017)

The aim of this research was to evaluate the cement solidification / stabilization through study the leaching characteristics of four different synthetic heavy metal wastes (Chromium, Iron, Zinc, and Manganese ions) and finally determine the strength of cement based on S/S by unconfined compressive strength testing.

\section{EXPERIMENTAL WORK}

\section{Preparations samples of contaminated sand}

In the beginning, the raw materials were prepared. The sand (type A) was purchased from the Al-Akhdar site in Karbala. The sand was sieved and washed with water to get rid of the salts, then dried under the sun for 5 days, before being sieved to match the particle size distribution shown in Figure 1. Heavy metal ions were prepared from standard salts to be liquid solutions at a concentration of $10000 \mathrm{ppm}$. The heavy metal reagents were sprayed on a calculated amount of sand samples to obtain concentrations of $500 \mathrm{mg} /$ $\mathrm{kg}, 1500 \mathrm{mg} / \mathrm{kg}$, and $3000 \mathrm{mg} / \mathrm{kg}$. The samples were stored in a dark place at room temperature; the sand was divided into groups of each one 150 percent of the weight to start the molds. All molds had a fixed weight, and Table 1 shows the properties of the metal ions used in the study.

\section{Specimen's preparations and mixing procedure}

Solidification / stabilization was performed according to the ordinary cement paste mixing procedure ASTM C305. The sand was contaminated with metal oxides, specifications of Ordinarily Portland cement type (A) listed in Table 2.

The weight of the cement was prepared as a fraction of the weight of the sand, as $7 \%, 15 \%$, $25 \%$ weight of $1 \mathrm{~kg}$ of sand. A constant water (W) to dry OPC binder (DB) ratio of (0.45) was maintained at all times. Using low water to cement ratios is well-known to achieve better physical immobilization as it produces fewer pores in the solidified matrix. The reason behind using such relatively high water to cement ratio was to achieve workability and to allow for moulding flexibility of the product mortar. A good workability of a cement mix means the ability of having good compaction and permits moulding, The mortar was then cast and compacted into a cylindrical PVC moulds of $(5 \mathrm{~cm}$ diameter by $10 \mathrm{~cm}$ height). The moulds were made especially for this study. The mixing was performed manually for (10 minutes) using a steel trowel and rubber gloves. A homogeneous consistency of the blend achieved. The mortar was then cast and compacted into afore-metnioned cylindrical PVC moulds. The mixing, compaction, moulding, de-moulding, and curing of the $\mathrm{S} / \mathrm{S}$ samples followed the ASTM C31/C31M standard procedure (ASTM, 2009).

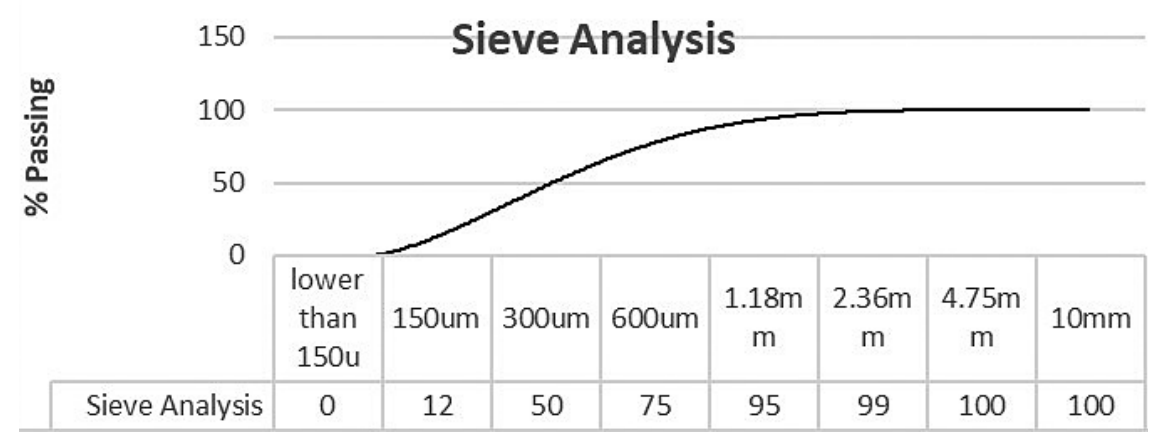

Fig. 1. Sieve analysis for the heavy metals contaminated sands used in the study 
Table 1. Characteristics of heavy metal ions used in the preparation of the targeted heavy metal ions

\begin{tabular}{|c|c|c|}
\hline $\begin{array}{c}\text { Targeted } \\
\text { heavy metal ion }\end{array}$ & $\begin{array}{c}\text { Chemical } \\
\text { formula }\end{array}$ & $\mathrm{MW}, \mathrm{g} / \mathrm{mol}$ \\
\hline Chromium & $\mathrm{CrCl}_{3} \mathrm{H}_{2} \mathrm{O}$ & 266.48 \\
\hline Zinc & $\mathrm{ZnO}$ & 81.379 \\
\hline Iron & $\mathrm{FeCl}_{3} \cdot 6 \mathrm{H}_{2} \mathrm{O}$ & 270.296 \\
\hline Manganese & $\mathrm{Cl}_{2} \mathrm{H}_{2} \mathrm{MnO}$ & 143.853 \\
\hline
\end{tabular}

Table 2. Characteristics of the cement used in the study

\begin{tabular}{|l|c|}
\hline \multicolumn{1}{|c|}{ Content } & Result \\
\hline Tri- calcium aluminates content (\%) & 6.42 \\
\hline Magnesium oxide content (\%) & 3.13 \\
\hline Third sulphur dioxide content (\%) & 2.38 \\
\hline Insoluble material content (\%) & 1.02 \\
\hline Combustion loss (\%) & 3.65 \\
\hline Limestone saturation factor & 0.96 \\
\hline Bulk density $\left(\mathrm{kg} \cdot \mathrm{m}^{-3}\right)$ & 1700 \\
\hline Particle size $(\mathrm{um})$ & 15 \\
\hline
\end{tabular}

\section{Experimental design}

In order to verify the effectiveness of the cement based of solidification/stabilization treatments to ions of the contaminated samples investigated in this study, the following tests carried out:

1. Unconfined compressive strength (UCS) testing

The strength of solidification waste is a concern in terms of disposal and landfilling (Cheng et al., 2013). The unconfined compression test device used to test the solid cylinder samples and follow the standard the American Standard Testing Methods protocol ASTM C-39 /C39M (ASTM. 2014). Where the permitted limits compressive strength must be achieved for any treatment and landfill, and the compressive strength is measured by dividing the maximum load on the sample during the test divided by the cross section area, the test was measured on three days: 7-28-60.

\section{Experimental design}

The procedure of toxicity characteristic leaching procedure (TCLP), that was employed according to Method 1311 (U.S. EPA 1992), the experiments were carried out for four + mix heavy metals pollutants at three contamination loads. For stability and solidified effectiveness, three different mix designs were used (Table 3), in addition to control mix design.

\section{Measurement of leaching properties}

In order to evaluate the leachability characteristics of the cement based solidified / stabilized samples, the toxicity characteristics leaching procedure TCLP was used according to (EPA test Method 1311) in this study. The mobility of inorganic analytics of solidified wastes was determined in this test. The crushed samples were sieved on a 9.5 sieve, taking $100 \mathrm{~g}$ of passing-sieve and $100 \mathrm{~g}$ of residual weight on sieve, after the agitation period, the samples than left to settle, then the extraction fluid was separated from the solid, the extraction fluid was filtered after collection and taken to laboratory for analysis.

Table 3. Experimental Matrix

\begin{tabular}{|c|c|c|c|c|}
\hline \multicolumn{3}{|c|}{ Heavy metal } & \multicolumn{2}{|c|}{ TCLP test METHOD 1311 Particle Size } \\
\hline \multicolumn{2}{|c|}{ Contamination load, $\mathrm{mg} / \mathrm{kg}$} & Mix Design & Particle size $<9.5 \mathrm{~mm}$ & Particle size $>9.5 \mathrm{~mm}$ \\
\hline \multirow{3}{*}{$\mathrm{Zn}$} & 500 & $\mathrm{M} 1, \mathrm{M} 2, \mathrm{M} 3$ & * & * \\
\hline & 1500 & $\mathrm{M} 1, \mathrm{M} 2, \mathrm{M} 3$ & * & * \\
\hline & 3000 & $\mathrm{M} 1, \mathrm{M} 2, \mathrm{M} 3$ & * & * \\
\hline \multirow{3}{*}{$\mathrm{Cr}$} & 500 & $\mathrm{M} 1, \mathrm{M} 2, \mathrm{M} 3$ & * & * \\
\hline & 1500 & $\mathrm{M} 1, \mathrm{M} 2, \mathrm{M} 3$ & * & * \\
\hline & 3000 & $\mathrm{M} 1, \mathrm{M} 2, \mathrm{M} 3$ & * & * \\
\hline \multirow{3}{*}{$\mathrm{Mn}$} & 500 & $\mathrm{M} 1, \mathrm{M} 2, \mathrm{M} 3$ & * & * \\
\hline & 1500 & $\mathrm{M} 1, \mathrm{M} 2, \mathrm{M} 3$ & * & * \\
\hline & 3000 & $\mathrm{M} 1, \mathrm{M} 2, \mathrm{M} 3$ & * & * \\
\hline \multirow{3}{*}{$\mathrm{Fe}$} & 500 & $\mathrm{M} 1, \mathrm{M} 2, \mathrm{M} 3$ & * & * \\
\hline & 1500 & $\mathrm{M} 1, \mathrm{M} 2, \mathrm{M} 3$ & * & * \\
\hline & 3000 & $\mathrm{M} 1, \mathrm{M} 2, \mathrm{M} 3$ & * & * \\
\hline \multirow{3}{*}{$\operatorname{mix}$} & 500 & $\mathrm{M} 1, \mathrm{M} 2, \mathrm{M} 3$ & * & * \\
\hline & 1500 & $\mathrm{M} 1, \mathrm{M} 2, \mathrm{M} 3$ & * & * \\
\hline & 3000 & $\mathrm{M} 1, \mathrm{M} 2, \mathrm{M} 3$ & * & * \\
\hline
\end{tabular}




\section{RESULTS AND DISCUSSION}

\section{Results of unconfined compression strength}

The initial design of (control reference) the samples was free of additives. Contaminated samples (150) were designed and divided into three groups to measure the unconfined compression strength. The first group consisted of 50 samples were examined after 7 days, after a week of immersion in water. The second group was examined after 28 days and the third group after 60 days. The the samples with mix contamination were also tested in unconfined compression strength on 7, 28 and 60 days.

The mean maximum loads applied on the cylindrical samples were recorded at the fracture point. These forces were used to calculate unconfined compression strength of the samples using the following equation (Ruseel. 2004):

$$
U C S=P / A
$$

where: UCS: Unified compressive strength (MPa) $P$ : The total recorded maximum load $(\mathrm{N})$ $A$ : Area of the loaded surface $\left(\mathrm{mm}^{2}\right)$

The result of the unconfined compression strength for specimens contaminated with 500, $1500,3000 \mathrm{mg} / \mathrm{kg}$ metal ions and (S/S) with 7 day were shown in Figures (2), (3), (4).

The compressive strength test was conducted after 7 days of immersion in water, in three percentages of cement and 3 different ratios of heavy metals at the concentration of $500 \mathrm{mg} / \mathrm{kg}, 1500$ $\mathrm{mg} / \mathrm{kg}$, and $3000 \mathrm{mg} / \mathrm{kg}$ of metal and the percentage of cement $7 \%, 15 \%$ and $25 \%$. The samples containing iron exhibited a low compressive strength with the metal-free samples (control reference) indicating that the metal cement paste was not affected during that period by the metal adsorption or that effect was insignificant. The chromium samples and metal mixture samples have the same result of iron on compressive strength, with the metal-free model (control reference) in all periods test. However, manganese and zinc were given high compressive strength compared with the metal-free model (control reference), due to function of the metal ion type, concentration of ions, and the OPC content used during the $\mathrm{S} / \mathrm{S}$ process. Heavy metal ions inhibit homogeneous nucleation or heterogeneous nucleation and growth of hydration products and in some cases enhance the silicate polymerization. (Chen, 2004) agrees with this analysis in iron and manganese.
These results of the unconfined compression strength for the specimens contaminated with 500 $\mathrm{mg} / \mathrm{kg}, 1500 \mathrm{mg} / \mathrm{kg}$, and $3000 \mathrm{mg} / \mathrm{kg}$ metal ions and S/S with 28 day were shown in Figures 5, 6 and 7 . The changes in this ratio of contamination during this period are shown below.

At the concentration of 500, 1500 and $3000 \mathrm{mg}$ per $\mathrm{kg}$ of metal and the percentage of cement $7 \%, 15 \%$ and $25 \%$, there was no sudden change. The compressive strength of all samples remained balanced against the reference control samples. However, the only change that happened

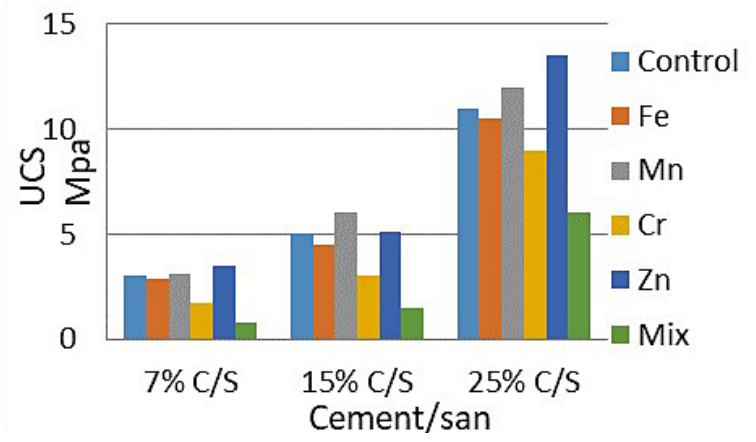

Fig. 2. Uncompressed compressive strength of samples contaminated with $500 \mathrm{mg} / \mathrm{kg}$ of heavy metal ions in $\mathrm{S} / \mathrm{S}$ after immersion for 7 days

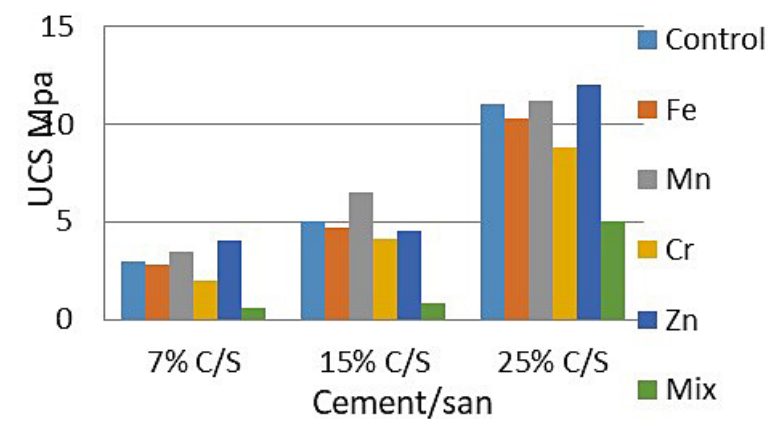

Fig. 3. Uncompressed compressive strength of samples contaminated with $1500 \mathrm{mg} / \mathrm{kg}$ of heavy metal ions in $\mathrm{S} / \mathrm{S}$ after immersion for 7 days

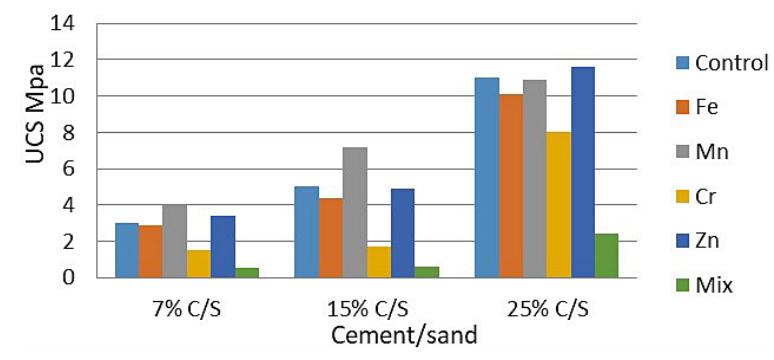

Fig. 4. Uncompressed compressive strength of samples contaminated with $3000 \mathrm{mg} / \mathrm{kg}$ of heavy metal ions in S/S after immersion for 7 days 


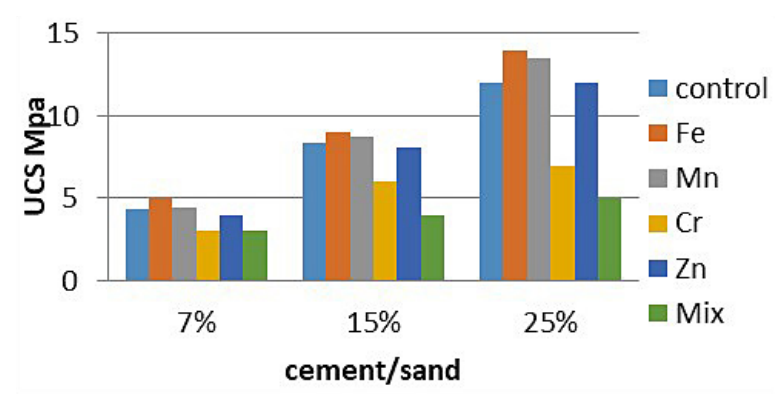

Fig. 5. Uncompressed compressive strength of samples contaminated with $500 \mathrm{mg} / \mathrm{kg}$ of heavy metal ions in $\mathrm{S} / \mathrm{S}$ after immersion for 28 days

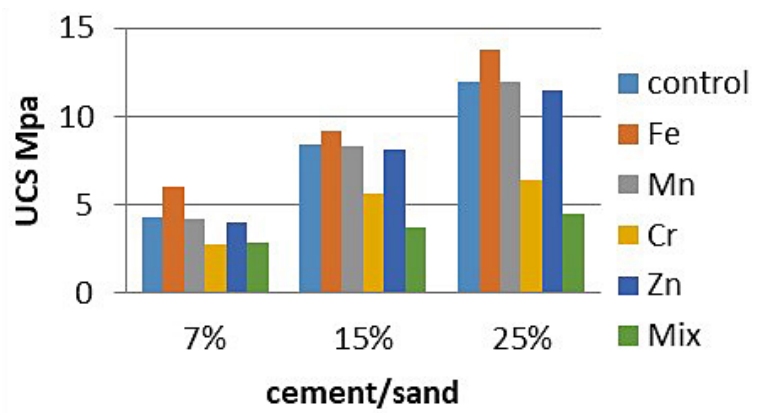

Fig. 6. Uncompressed compressive strength of samples contaminated with $1500 \mathrm{mg} / \mathrm{kg}$ of heavy metal ions in $\mathrm{S} / \mathrm{S}$ after immersion for 28 days

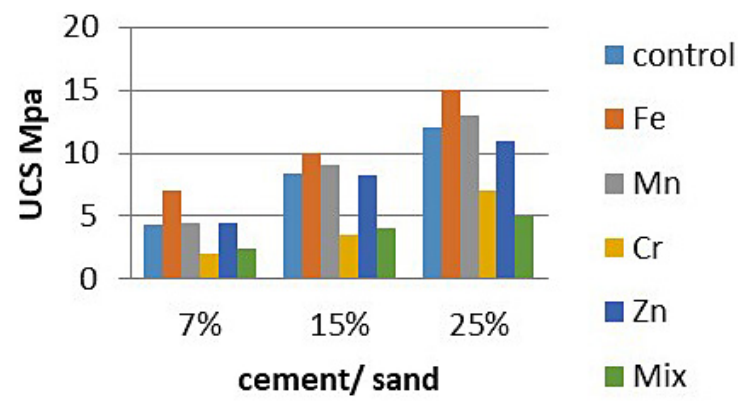

Fig. 7. Uncompressed compressive strength of samples contaminated with $3000 \mathrm{mg} / \mathrm{kg}$ of heavy metal ions in $\mathrm{S} / \mathrm{S}$ after immersion for 28 days

was that iron container samples increased compressive strength by as much as $70 \%$ compared to the reference mix. The reason for this is that iron strengthens the structural network of cement. The increase of the so-called immobilization degree with time of hardened material maturing was found. This should be attributed to the pozzolanic or pozzolanic/hydraulic properties of components used; their effect on microstructure of hardened material is also important. Mineral additions enter the hydration reactions in the mixtures and favor the formation of specific microstructure promoting the immobilization of hazardous elements.
These results agree with the ones obtained by (Giergiczny, et al., 2008). The results of the unconfined compression strength for specimens contaminated with $500 \mathrm{mg} / \mathrm{kg}, 1500 \mathrm{mg} / \mathrm{kg}$, and $3000 \mathrm{mg} / \mathrm{kg}$ metal ions and S/S with 60 day were shown in Figures 8, 9 and 10.

At the concentration of $500 \mathrm{mg} / \mathrm{kg}, 1500$ $\mathrm{mg} / \mathrm{kg}$ and $3000 \mathrm{mg} / \mathrm{kg}$ of heavy metal, and the percentage of cement $7 \%, 15 \%$ and $25 \%$, these results show similarity to the results from 28 days.

Standard Specification established the minimum requirements for compressive strength of secondary wastes and their disposal in the land (0.4 MPa) (NRC., 1991; EPA, 2014). During this study, all cement-based samples were found to not to have exceeded the required standard. The use of cement based ( $25 \%$ OPC by weight) in the mixture in the $\mathrm{S} / \mathrm{S}$ process. It is very suitable for treating the wastes containing heavy metal ions at the site or in the landfill, when the initial concentrations of heavy metal ions are high $(3000 \mathrm{mg} / \mathrm{kg})$.

This study shows three factors effects on the unconfined compressive strength, these factors are types and concentration of heavy metal, ratio of binder to media composition, and the period required for curing.

\section{Results of toxicity characteristic leaching procedure (TCLP) tests}

The EPA method 1311 (USEPA 1990) used in the $\mathrm{S} / \mathrm{S}$ processes study to measure the TCLP Leaching tests carried after 28 days of treatment. The method summarizes two TCLP runs, for each of the samples after grinding and crushing, the first operation for the particles $<9.5 \mathrm{~mm}$ in size, and the second is for the particles $>9.5$ of

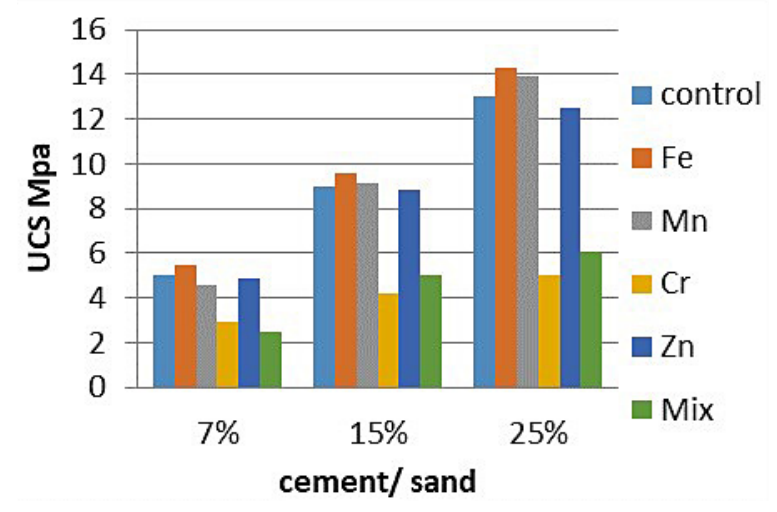

Fig. 8. Uncompressed compressive strength of samples contaminated with $500 \mathrm{mg} / \mathrm{kg}$ of heavy metal ions in $\mathrm{S} / \mathrm{S}$ after immersion for 60 days 


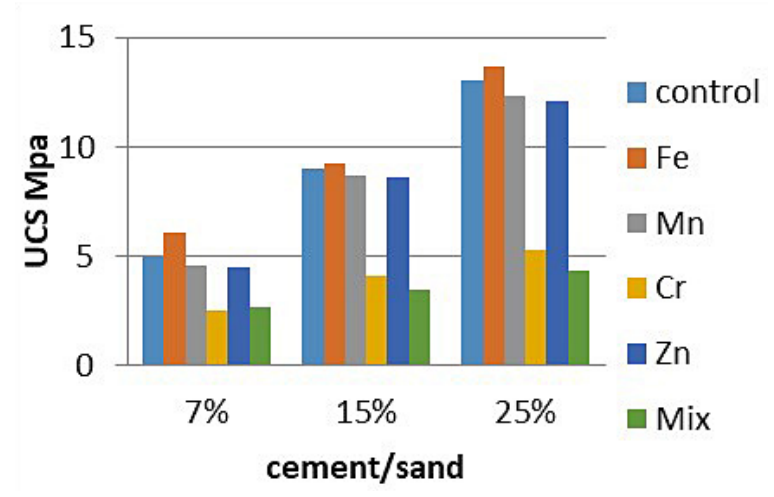

Fig. 9. Uncompressed compressive strength of samples contaminated with $1500 \mathrm{mg} / \mathrm{kg}$ of heavy metal ions in S/S after immersion for 60 days

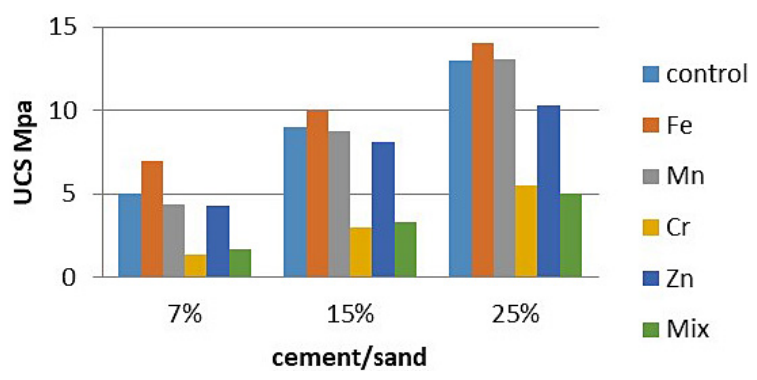

Fig. 10. Uncompressed compressive strength of the samples contaminated with $3000 \mathrm{mg} / \mathrm{kg}$ of heavy metal ions in $\mathrm{S} / \mathrm{S}$ after immersion for 60 days

the particles size. The results showed that all the leachate concentrations of the pollutant (heavy metals) decreased with the increase of cement added to the mixture design (Figures 11 to 14). It was also observed that the increased in particles size for samples of $\mathrm{S} / \mathrm{S}$, are more effective in containing and retaining the heavy metal in the samples. It was noted the sample containing the concentration of manganese ion at $1500 \mathrm{mg} / \mathrm{kg}$, with cement mix ration at $7 \%, 15 \%$ and $25 \%$ had a TCLP test recorded value of $14.4 \mathrm{mg} / 1,7.6 \mathrm{mg} / 1$ and $4.8 \mathrm{mg} / 1$, respectively.
For the same samples for the particles $>9.5 \mathrm{~mm}$ in size, which were used in TCLP test, the concentrations of contaminants (heavy metals) decreased to $11.9 \mathrm{mg} / 1,4.6 \mathrm{mg} / \mathrm{l}$ and $2.8 \mathrm{mg} / \mathrm{l}$, respectively. The same behavior was observed in the TCLP test of the S/S samples contaminated with manganese and chromium and Zinc ions. In this study, it was observed that two factors have indication on leaching properties of heavy metals in the acid solution, the size of the particles, and the concentration of cement in the design of the $\mathrm{S} / \mathrm{S}$ mixture, and there are several other observations found in other studies (Olcay, 2003). The following equation (2) was used to calculate the amount of released metals and the percentage of metals retained in the $\mathrm{S} / \mathrm{S}$ samples.

$$
R T \%=\left(\left(C_{0}-C_{1}\right) / C_{0}\right) \cdot 100
$$

where: $R T \%$ : Retention efficiency.

$C_{0}$ : Inertial metal concentration, mg.

$C_{1}$ : Metal concentration in leachate, $\mathrm{mg}$.

The results show that the S/S samples had a high retention efficiency of more than $93 \%$ for all samples when a $25 \%$ cement content ratio with the initial pollutant concentration was $3000 \mathrm{mg} / \mathrm{kg}$, The results of the retention efficiency of heavy metals and the different mixing designs and heavy metals ratios were shown in (Table 4). On the other hand, 15\% cement mix designs of $\mathrm{S} / \mathrm{S}$ samples were highly efficient in retaining heavy metals. These retention percentage values can be used to assess the effectiveness of the stabilization process.

Although the low cement content in the $\mathrm{S} / \mathrm{S}$ mixture design contains the lowest ratio of Retention percentage, they yield reasonable and acceptable values of the events for all samples recording $>45.5 \%$. It was observed that the highr percentage of cement in the mixture design, the

Table 4. Heavy metals retention efficiencies for the solidified / stabilized samples

\begin{tabular}{|c|c|c|c|c|c|c|c|c|c|c|c|c|c|c|c|c|c|c|}
\hline \multicolumn{19}{|c|}{ Retention efficiency of heavy metals in s/s cement based samples $\%$} \\
\hline $\begin{array}{l}\text { Contamination } \\
\text { load, } \mathrm{mg} / \mathrm{kg}\end{array}$ & \multicolumn{6}{|c|}{500} & \multicolumn{6}{|c|}{1500} & \multicolumn{6}{|c|}{3000} \\
\hline $\begin{array}{l}\text { Mix design } \\
\text { cement addition }\end{array}$ & \multicolumn{2}{|c|}{7} & \multicolumn{2}{|c|}{15} & \multicolumn{2}{|c|}{25} & \multicolumn{2}{|c|}{7} & \multicolumn{2}{|c|}{15} & \multicolumn{2}{|c|}{25} & \multicolumn{2}{|c|}{7} & \multicolumn{2}{|c|}{15} & \multicolumn{2}{|c|}{25} \\
\hline Partical size, $\mathrm{mm}$ & $<9.5$ & $>9.5$ & $<9.5$ & $>9.5$ & $<9.5$ & $>9.5$ & $<9.5$ & $>9.5$ & $<9.5$ & $>9.5$ & $<9.5$ & $>9.5$ & $<9.5$ & $>9.5$ & $<9.5$ & $>9.5$ & $<9.5$ & $>9.5$ \\
\hline \multicolumn{19}{|l|}{ Metal ions, \% } \\
\hline Chromium & 90.5 & 92 & 92.1 & 97.2 & 96 & 96 & 85 & 91 & 93 & 96 & 97 & 55 & 61 & 75 & 88 & 89 & 95 & 96 \\
\hline Iron & 87.3 & 93.2 & 96.2 & 97.1 & 98.2 & 99 & 95 & 87 & 89 & 91 & 94 & 95 & 91 & 89 & 90 & 89 & 92 & 95 \\
\hline Zinc & 92 & 95 & 95.3 & 97 & 96 & 97 & 94 & 93 & 94 & 97 & 98 & 97.5 & 83 & 87 & 90 & 93 & 94 & 93 \\
\hline Magneases & 90.1 & 92 & 93 & 97 & 98 & 99 & 80 & 75 & 78 & 90 & 92 & 65 & 70 & 81 & 87 & 91 & 93 & 96 \\
\hline
\end{tabular}




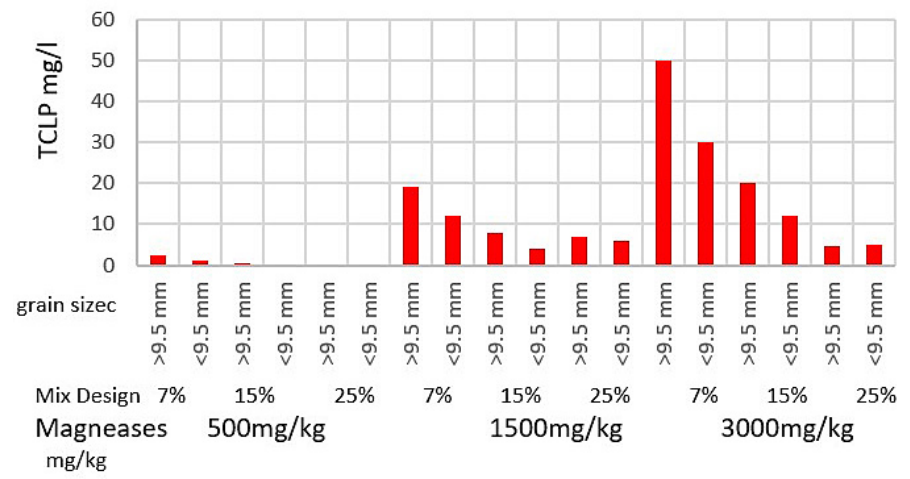

Fig 11. TCLP leachate test results for the Manganese ions contaminated samples

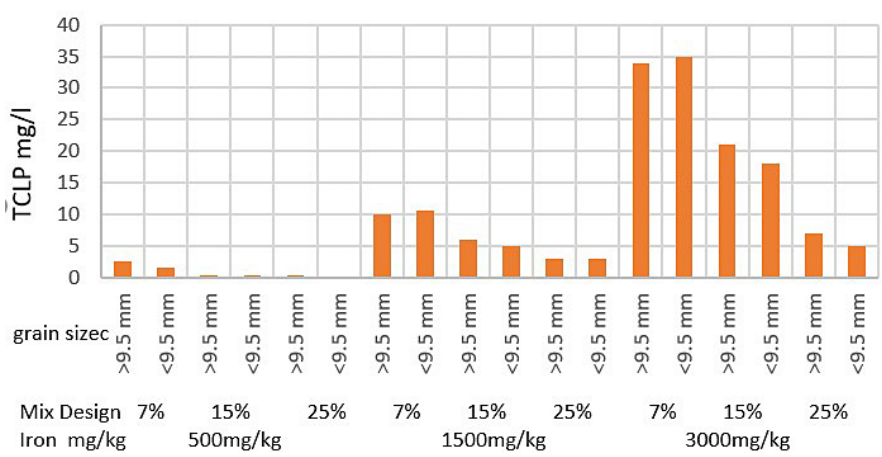

Fig. 12. TCLP leachate test results for the Iron ions contaminated samples

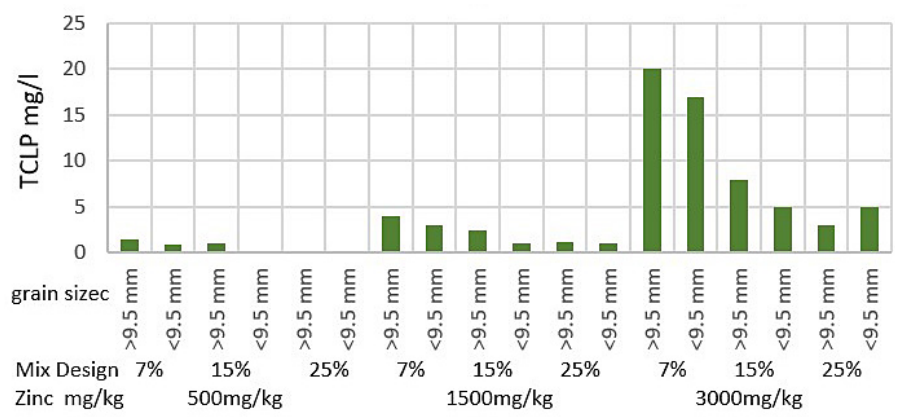

Fig. 13. TCLP leachate test results for the Zinc ions contaminated samples

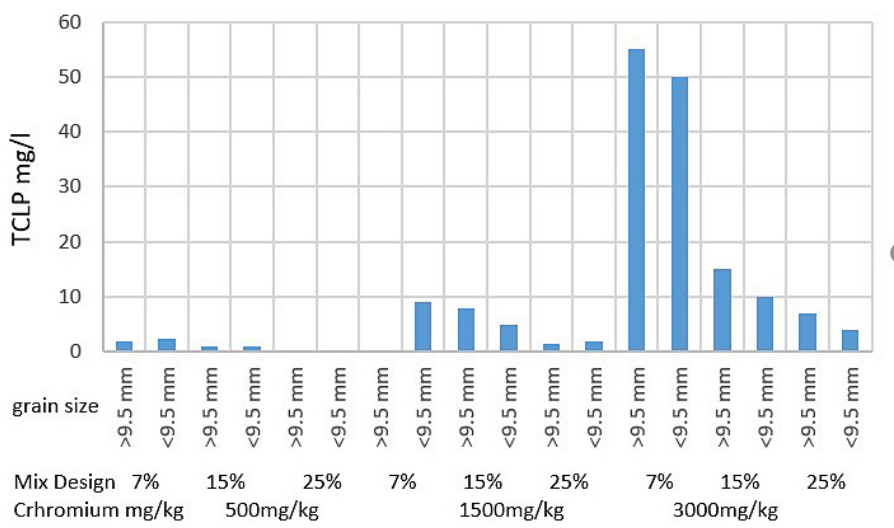

Fig. 14 . TCLP leachate test results for the Chromium ions contaminated samples 
coarser of particle size in the solidified matrix, which leads to an increase in the treatment efficiency, and treatment processes due to the increase the RT\%, as shown in Table 4. Despite the higher RT\% that was detected for most samples, some heavy metal ions leached such as chromium, iron and manganese from the cement ratio in the mix 7\% and exceeded the regulatory limits set of TCLP by the US Environmental Protection Agency U.S EPA $(50 \mathrm{mg} / 1,50 \mathrm{mg} / \mathrm{l}$ and $10 \mathrm{mg} / 1 \mathrm{respectively),} \mathrm{these} \mathrm{results} \mathrm{are} \mathrm{shown}$ in Figures 11-14. This may be due to the initial high load of heavy metals in the samples and poor solidification. Similar observations were found in other studies (Chen et al., 2009). The initial value of the $\mathrm{pH}$ of the extraction solution in this study was 4.9 and after 18 hours of agitation samples of $\mathrm{S} / \mathrm{S}$, the $\mathrm{pH}$ of the extraction solution rose to more than 9 because of the nature of the cement used in the base mixture (Nicholas, 2009). This shows that there is a proportional relationship between the cement content of the samples and the final $\mathrm{pH}$ of the liquid extraction.

\section{CONCLUSION}

In this study it was found that the method of solidification / stabilization is a good and effective technique against the release of heavy metals $(\mathrm{Fe}, \mathrm{Zn}, \mathrm{Fe}$, and $\mathrm{Cr}$ ) which contaminated the sand and add to cement in mixture design. The range of unconfined compressive strength values ranged 1-15 $\mathrm{MPa}$, all samples were within the standard determinants of the US EPA. In addition, the OPC content is $25 \%$ in $\mathrm{S} / \mathrm{S}$ operations was good enough to meet regulatory values of U.S EPA. Additionally, the zinc ion concentration in $500 \mathrm{mg} / \mathrm{kg}, 1500 \mathrm{mg} / \mathrm{kg}$ and $3000 \mathrm{mg} / \mathrm{kg}$ through solidified / stabilized Matrix process, caused an increase in the compressive strength especially in the early ages. However, we observed an increased compressive strength of the later ages. When we added the concentration of iron ion to the mixture design through solidified / stabilized matrix process, due to increased cement content, and increases in particle size lead to decreased leaching of heavy metals. All samples containing $15-25 \%$ of the cement added in the S/S processes are consistent with the TCLP regulatory limits set, by the EPA to dispose of heavy metals at the site, and solidification/ stabilization method is still considered indispensable in the treatment and management of waste.

\section{REFERENCES}

1. ASTM C31/C31M-09 (2009) Standard Practice for Making and Curing Concrete Test Specimens in the Field American Society for Testing and Materials.

2. ASTM C39 / C39M-14a, Standard Test Method for Compressive Strength of Cylindrical Concrete Specimens, ASTM International, West Conshohocken, PA, 2014,

3. Balamohan Balakrishnan, A.S.M. Abdul Awal, Abdul Halid B. Abdullah and M.Z. Hossain 2017. Flow Properties And Strength Behaviour Of Masonry Mortar Incorporating High Volume Fly Ash. International Journal of GEOMATE, March, 2017, Vol. 12, Issue 31, pp. 121-126, doi: http://dx.doi. org/10.21660/2017.31.19763.

4. Bone, B.D. Barnard, L.H. Boardman, D,I,. Carey, P.J,. Hills, C,D,. Jones, H.M,. Macleod, C, and Tyrer, M. 2004. Review of scientific literature on the use of stabilization/ solidification for the treatment of contaminat soil, solid waste and sludges. Environment Agency, Bristol.

5. Borowski G., Hycnar J.J. 2016. The effect of granulated fly ashes with phosphogypsum on the hardening of cement mortar. Technical Transactions - Civil Engineering, Vol. 113, Iss. 2-B (7), 37-45.

6. Chen Q.Y., 2004. Examination of Hydrated and Accelerated Carbonated Cement - Heavy Metal Mixtures. P.hD. Thesis, University of Greenwich, London, UK.

7. Chen Q.Y, Tyrer M., Hills C.D., Yang X.M. and Carey P. 2009. Immobilization Of Heavy Metals In Cement - Based Solidification / Stabilization: A review. Journal of Waste Management 29, 390-403.

8. Cheng L., Wei Z., d Jie H. 2013. Strength and Leachability of Solidified Sewage Sludge With Different Additives. J. Matter Civ Eng, 25, 1594-1601.

9. Cioffi R, Lavorgna M, Santoro L 2002. Environmental and technological effectiveness of a process for the stabilization of a galvanic sludge. J Hazard Mater B89(2-3),165-175.

10. Conner J.R. and Hoeffner S.L. 1998. The history of stabilization/solidification technology. Crit. Rev. Env. Sci. Technol. 28, 325-396.

11. Coz A, Andres A, Soriano S, Irabien A. 2004. Environmental behaviourof stabilised foundry sludge. $\mathrm{J}$ Hazard Mater B109(1-3), 95-104.

12.EPA, 2014, National waste Management plan 2014-2020.

13. Giergiczny Z., Król A. 2008. Immobilization of heavy metals ( $\mathrm{Pb}, \mathrm{Cu}, \mathrm{Cr}, \mathrm{Zn}, \mathrm{Cd}, \mathrm{Mn})$ in the mineral additions containing concrete composites. J Hazard Mater. 160(2-3), 247-55. doi: 10.1016/j. jhazmat.2008.03.007.

14. Hansen L.G and Chaney R.L. 1984. Environmental 
And Food Chain Effects Of The Agricultural Use Of Sewage Sludges. Rev Environ Toxicol, Vol. 1, 103-110.

15. Kimbrough D.E., Cohen Y., Winer A.M., Creelman L., Mabuni C, 1999. A Critical Assessment of Chromium in the Environment. Crit Rev Environ Sci Technol 29(1), 1-46.

16. Kitamura M., Konno H., Yasui A., Masuoka H. 2002. Controlling Factors and Mechanism of Reactive Crystallization of Calcium Carbonate Polmorphs from Calcium Hydroxide Suspension. Journal of Crystal Growth 236, 323-332.

17. La Grega M.D., Buckingham P.L., Evans J.C., 1994. Hazardous Waste Management, McGrawHill, New York.

18. Malviya R., Chaudhary R., 2006. Factors Affecting Hazardous Waste Solidification/ Stabilization: A Review. Journal of Hazardous Materials 137, 267-276.

19. Winter N.B., 2009. Understanding Cement: An Introduction to Cement Production, Cement Hydration and Deleterious Processes in Concrete. WHD Microanalysis Consultants Ltd Woodbridge, United Kingdom.

20. NRC-U.S. Nuclear Regulatory Commission, 1991. Waste Forms Technical Position, Revision 1. U.S Nuclear Regulatory Commission. Washington .D.C.

21. Yilmaz O., Unlu K., Cokca E. 2003. Solidification / Stabilization Of Hazardous Wastes Containing Metals And Organic Contaminants. J. Environ. Eng, 129, 366-376.
22. Rijkenberg M.J., Depree C.V. 2010. Heavy Metal Stabilization in Contaminated Road-Derived Dediments. Sci Total Environ 408, 1212-1220.

23. Russell C.H. 2004. Mechanics of Materials. 6th ed., Verlag: Prentice Hall .Germany.

24. Silva MAR, Mater L, Souza-Sierra MM, Corre^a AXR, Sperb R, Radetski CM. 2007. Small hazardous waste generators in developing countries: use of stabilization/solidification process as an economic tool for metal wastewater treatment and appropriate sludge disposal. J Hazard Mater 147(3), 986-990.

25. Shi C., Spence R., 2004. Designing of Cement Based Formula for Solidification /Stabilization of Hazardous, Radioactive, and Mixed Wastes. Crit. Rev. Env. Sci.Technol. 34, 391-417.

26. Tomasevic D.D., Dalmacija M.B., Prica M.D., Dalmacija B.D., Kerkez D.V., Bečelić-Tomin M.R., Roncevic S.D. 2013. Use of Fly Ash for Remediation of Metals Polluted sediment. Green Remediation. Chemosphere 92, 1490-1497.

27. USEPA 1990, USEPA Method 1311, EPA 1990. Test method.

28. U.S. EPA. 1992. Method 1311: toxicity characteristic leaching procedure. In EPA SW-846: test methods for evaluating solid waste, physical/chemical methods, July 1992.

29. U.S EPA 2004. Treatment Technologies For Site Cleanup, Annual status report (eleventh edition), EPA -542-R-03-009.

30. Wiles C.C., 1987. A Review of Solidification / stabilization technology. J. Haz. Mat., 14(1), 5-21. 